\title{
Changes in sediment properties and bacterial community in marine sediments after entering the coastal land in Bohai Bay, northern China
}

\author{
Xin Sui ${ }^{1,2}$, Huijun Gu ${ }^{1,2}$, Meiqing Jia ${ }^{3}$, Chengbao Liu ${ }^{1,2}$, Meiqi Liu ${ }^{1,2}$, Zhiwei Gao ${ }^{1,2}$, \\ and Guogang Zhang ${ }^{1 *, 2}$
}

\begin{abstract}
${ }^{1}$ Tianjin Normal University, College of Life Sciences, Binshuixidao 393, Xiqing District, 300387 Tianjin, China. *Corresponding author (zhangguoganglab@163.com).

${ }^{2}$ Tianjin Normal University, Tianjin Key Laboratory of Animal and Plant Resistance, Binshuixidao 393, Xiqing District, 300387 Tianjin, China.

${ }^{3}$ Tianjin Normal University, Key Laboratory of Water Resource and Environment, Binshuixidao 393, Xiqing District, 300387 Tianjin, China.
\end{abstract}

Received: 26 October 2019; Accepted: 3 January 2020; doi:10.4067/S0718-58392020000200181

\begin{abstract}
In coastal areas of Bohai Bay, China, marine sediments were used for land reclamation. However, vegetation cannot grow well on the reclaimed land because marine sediments have different ecological functions than soil. Changing marine sediment into soil rapidly and accelerating the soil-forming process is key to solving this ecological problem on reclaimed land. Therefore, in this study, we not only measured the chemical properties of marine sediments during an $8 \mathrm{yr}$ soil formation period to explore fertility changes, but we also used MiSeq sequencing to analyze and compare the bacterial community structure and diversity before and after the $8 \mathrm{yr}$ land reclamation. Our results showed: (1) Marine sediment changed from severe to mild salinization during the $8 \mathrm{yr}$ of soil formation, and the sediment salinity decreased significantly to $7.3 \mathrm{~g} \mathrm{~kg}^{-1}(p<0.05)$. However, $\mathrm{pH}$ of the sediment was always $>8.5$ and did not change significantly. In addition, the total fertility of the sediment decreased significantly after $8 \mathrm{yr}$. Especially, the content of nitrate- $\mathrm{N}$ in marine sediment decreased significantly by $86.23 \%(p<0.05)$ after 8 yr of soil formation. Also, the content of available P and soil organic matter decreased significantly by $45.92 \%$ and $26.22 \%$, respectively. (2) The total abundance of bacteria increased while the community diversity decreased after the sediments were removed from the ocean environment for 8 yr. The bacterial community composition changed, and results of our redundancy analysis (RDA) indicated that the change was mainly affected by $\mathrm{pH}$, soil contents including, available $\mathrm{P}$, nitrate- $\mathrm{N}$, ammonia- $\mathrm{N}, \mathrm{Na}^{+}$, and $\mathrm{Cl}^{-}$, as well as salinity .
\end{abstract}

Key words: MiSeq sequencing, marine sediments, sediment bacteria, soil fertility, soil property.

\section{INTRODUCTION}

Bohai bay is located in northern China and Tianjin port is one of its representative areas. Marine sediments were extracted from Tianjin port and used for land reclamation project. In Tianjin, the land reclamation is an important way to utilize marine resources, and is also an effective way to expand port, industrial space and urban construction. The area of reclaimed land in Tianjin has increased to $2.79 \times 10^{8} \mathrm{~m}^{2}$ until 2018. However, vegetation cannot grow well on the reclaimed land due to high salinity and $\mathrm{pH}$ of the sediment. The added marine sediments were not soil, and therefore, do not have the same ecological function as soil (e.g. salinity > 1\%, pH > 8.0) (Tuteja, 2007; Waskiewicz et al., 2013). Generally, after adding extracted marine sediments to coastal land, sediments change to soil naturally over a long timescale (decades to millennia) in response to soil-forming factors (Wills et al., 2016). 
Some researchers believe that artificial intervention can potentially shorten the process of soil formation and they have, therefore, made efforts to improve the quality of marine sediments. For example, in terms of physical and chemical properties, some scholars filled sediment with gypsum, bran, waste or sand to improve the marine sediment (Guo et al., 2005; Wang et al., 2011; Jin, 2013; Tian, 2014). Additionally, from a bioremediation perspective, some scholars proposed planting halophytes to improve sediment quality (Zou et al., 2010). However, these measures have only been effective for a short period of time with no long-lasting effects, and the cost of manpower and resources is uneconomical.

There are five main factors of soil formation including, soil parent material, climate, biota (organisms), topography, and time (Wills et al., 2016). Among them, the biota is the most significant factor which can be intervened by human beings. Researchers found that seabed sediment is among the most important habitats for marine microorganism survival, but presents extreme living conditions including, high salinity, high alkalinity, high pressure (deep sea), low temperature (deep sea and polar region), and high temperature (deep-sea hydrothermal vent) (Weiner et al., 1999). Throughout their evolutionary history, marine microorganisms acquired physiological and metabolic mechanisms as well as special morphological characteristics to adapt to these extreme environments (Logan and Regan, 2006; Sogin et al., 2006). Recent research showed that marine microorganisms not only play a significant role in the marine environment through biogeochemical cycles (Moran, 2015), but also have various functional uses including, the use of their enzymes in the microbial fuel cell (Logan and Regan, 2006; Du et al., 2007; Abbas et al., 2017), degrading oil contaminants (Mohanty and Mukherji, 2008; Okeke, 2008; Wang et al., 2012), cleaning heavy metal pollution (Mincer et al., 2002; Gupta et al., 2012; Chen et al., 2017), and providing useful bioactive compounds (Romano et al., 2017). However, there is a gap in knowledge regarding the use of marine microorganisms to improve the quality of marine sediment and thus accelerate the soil formation process.

Therefore, in this study, we evaluated 15 chemical properties of marine sediments to evaluate the change in soil properties and fertility during a period of soil formation. Additionally, by using next generation sequencing methods, we compared the composition and diversity of the sediment bacterial community before and after the $8 \mathrm{yr}$ land reclamation. Finally, the relationship between chemical properties and bacterial community of the marine sediment was also analyzed and discussed. Through the above three aspects, the objective of this study was to identify several key soil properties or sediment bacteria genus, which can accelerate the transformation of sediments to soil, and improve sediments in the reclamation area for further plant growth and even agricultural development.

\section{MATERIALS AND METHODS}

\section{Study site and soil-sediment sample collection}

Soil-sediment samples were collected from the Tianjin Port area (38 $59^{\prime} \mathrm{N}, 117^{\circ} 42^{\prime}$ E), Bohai Bay, China. As shown in Figure 1, there were six sampling sites including, S0, S1, S4, S6, S7, and S8, which correspond to areas where marine sediment was added to the coastal land for $0,1,4,6,7$, and $8 \mathrm{yr}$, respectively. Other sampling sites including, S2, S3, and $\mathrm{S} 5$, were inaccessible due to construction, and therefore, soil-sediment samples from these sites could not be collected. At each soil sampling site, topsoil $(0-30 \mathrm{~cm})$ samples were collected with three replicates. Each sample was packed into plastic bags and taken to the laboratory. Each sample was divided into two groups: a fresh sample was preserved at $-20{ }^{\circ} \mathrm{C}$ for further analysis of soil bacteria, and the other sample was air dried after gravel removal and sieved through two different sieves $(0.025$ and $0.015 \mathrm{~mm})$ to determine soil chemical properties. Only S0 and S8 soil-sediment samples were used to analyze the difference of sediments bacteria community before and after $8 \mathrm{yr}$ soil formation.

In this study, we quoted soil chemical properties of eight cropland sampling points in the New Coastal Region of Tianjin (Ma, 2011), which are located near the sediment sampling points used in the present study (Figure 1). Additionally, in the present study, every parameter was determined using the same methodology described by Ma (2011). This cropland soil has a near neutral $\mathrm{pH}$ and exhibits mild or moderate soil salinization. The mean value of each chemical property in the cropland sampling sites was used to validate the accuracy of the present data.

\section{Analysis of the chemical properties of the sediments}

Methods used to determine chemical properties of the sediments are summarized in Table 1. Additionally, 15 chemical properties were evaluated using principal component analysis (PCA) (Jolliffe, 1986; Wold et al., 1987; Liu et al., 2010a; 
Xie et al., 2015). The comprehensive score was used to evaluate the sediment fertility of each sample (Li et al., 1992; Qin et al., 2015). As each variable represents a single index of sediment fertility, the comprehensive score can represent the overall level of marine sediment fertility.

Figure 1. Map of Tianjin Port including sampling areas.

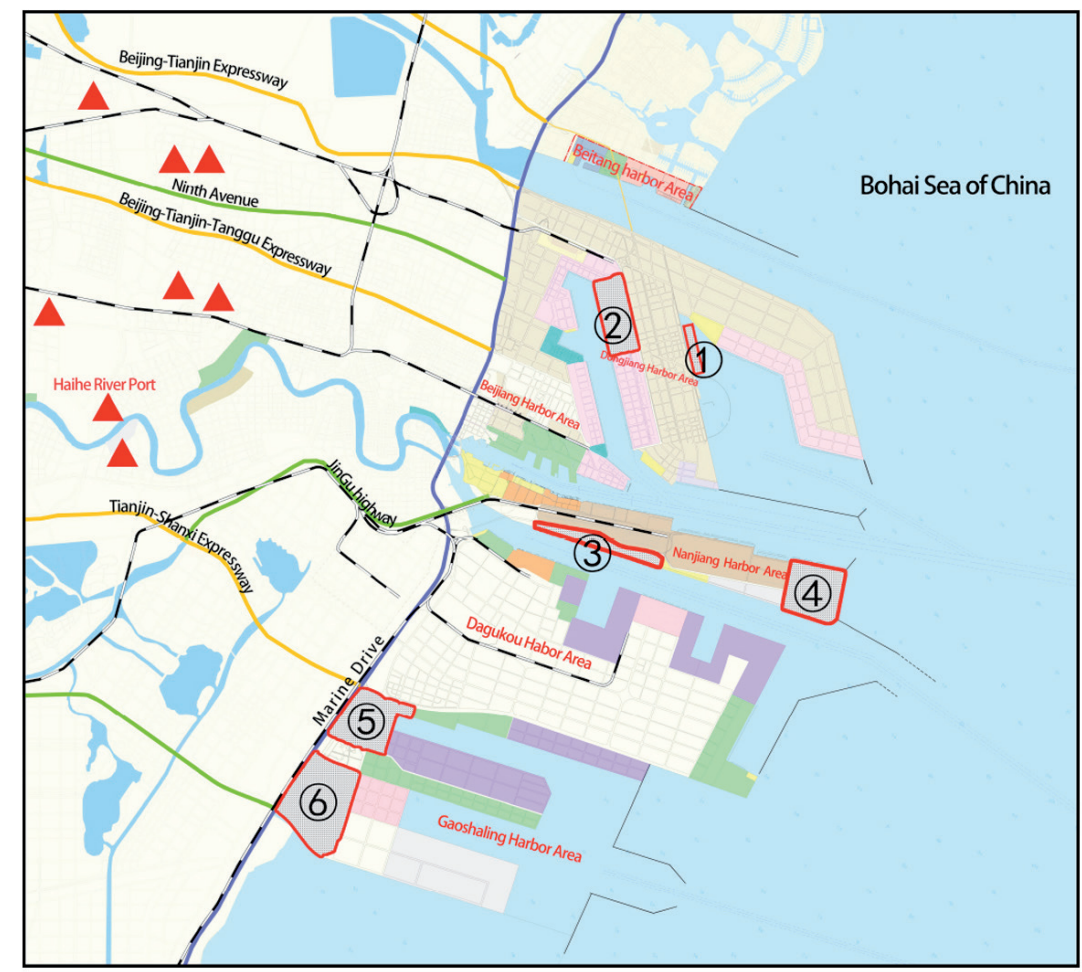

Red triangles: Cropland sites in the New Coastal Region of Tianjin which were previously sampled (Ma, 2011). Red boxes: sites sampled in the present study in Tianjin.

1. Sediment extracted in 2012, soil-sediment samples were collected in 2012; soil formation time was 0 yr (S0). 2. Sediment extracted in 2012 , soil-sediment samples were collected in 2013; soil formation time was $1 \mathrm{yr}$ (S1). 3. Sediment extracted in 2010, soil-sediment samples were collected in 2016; soil formation time was 6 yr (S6). 4. Sediment extracted in 2009, soil-sediment samples were collected in 2016; soil formation time was 7 yr (S7). 5. Sediment extracted in 2008, soil-sediment samples were collected in 2016; soil formation time was 8 yr (S8). 6. Sediment extracted in 2012, soil-sediment samples were collected in 2016; soil formation time was 4 yr (S4).

Table 1. Methods used to measure sediment chemical properties.

\begin{tabular}{ll}
\hline Chemical properties & \multicolumn{1}{c}{ Measured methods } \\
\hline $\mathrm{pH}$ & Potentiometry (Sui and Li, 2004) \\
$\mathrm{AK}$ & Ammonium acetate extraction and the flame photometric method (Sui and Li, 2004) \\
$\mathrm{AP}$ & Molybdenum blue colorimetric method (Sui and Li, 2004) \\
$\mathrm{SOM}$ & Potassium dichromate method (Sui and $\mathrm{Li}, 2004)$ \\
$\mathrm{EC}$ & FE3-type Mettler-Toledo conductivity meter \\
$\mathrm{K}^{+}$ & Flame photometry (Bao, 2000) \\
$\mathrm{Na}^{+}$ & Flame photometry (Bao, 2000) \\
$\mathrm{Ca}^{2+}$ & Atomic absorption spectrophotometry (422.7 $\mathrm{nm})(\mathrm{Bao}, 2000)$ \\
$\mathrm{Mg}^{2+}$ & Atomic absorption spectrophotometry $(285.2 \mathrm{~nm})(\mathrm{Bao}, 2000)$ \\
$\mathrm{Cl}^{-}$ & Silver nitrate titration (Bao, 2000) \\
$\mathrm{SO}_{4}{ }^{2-}$ & EDTA Indirect complex metric titration (Bao, 2000) \\
$\mathrm{Salinity}^{-}$ & Sum of the eight major ions (Bao, 2000) \\
$\mathrm{Nitrate}^{-\mathrm{N}}$ & Continuous flow analyzer (dissolution in potassium chloride) \\
$\mathrm{Ammonia}^{-N}$ & Continuous flow analyzer (dissolution in potassium chloride) \\
$\mathrm{HCO}_{3}^{-}$ & Double indicator-Neutralization titration (Bao, 2000) \\
\hline
\end{tabular}

AK: Available K; AP: available P; SOM: soil organic matter; EC: electrical conductivity. 


\section{Comprehensive fertility evaluation based on PCA}

PCA was used to analyze 15 chemical properties that represent the fertility level of sediment. Three principal components were extracted and the cumulative contribution rate was $91.834 \%$ (Table 2). Because the indicators in this experiment had different dimensions and orders of magnitude, we applied data standardization processing using SPSS software (IBM, Armonk, New York, USA) to eliminate these influences on the evaluation results and thus to ensure objectivity and accuracy of the evaluation. The standardized variables for each sample were denoted as Z1 to Z15.

The principal component is a linear combination of all standardized indexes, and the weight is the component score coefficients of each index (Table 2). Therefore, the linear combination of the three principal components and the 15 original indexes can be obtained as follows:

$$
\begin{array}{r}
\mathrm{F} 1=-0.022 \times \mathrm{Z} 1+0.107 \times \mathrm{Z} 2-0.085 \times \mathrm{Z} 3+0.101 \times \mathrm{Z} 4+0.086 \times \mathrm{Z} 5+0.091 \times \mathrm{Z} 6-0.008 \times \mathrm{ZZ}-0.106 \times \mathrm{Z} 8-0.014 \\
\times \mathrm{Z} 9+0.101 \times \mathrm{Z} 10+0.12 \times \mathrm{Z} 11+0.14 \times \mathrm{Z} 12-0.065 \times \mathrm{Z} 13+0.15 \times \mathrm{Z} 14-0.095 \times \mathrm{Z} 15 \\
\mathrm{~F} 2=0.160 \times \mathrm{Z} 1+0.045 \times \mathrm{Z} 2-0.065 \times \mathrm{Z} 3+0.112 \times \mathrm{Z} 4-0.157 \times \mathrm{Z} 5+0.127 \times \mathrm{Z} 6+0.186 \times \mathrm{Z} 7-0.122 \times \mathrm{Z} 8+0.046 \times \\
\mathrm{Z9}-0.111 \times \mathrm{Z} 10-0.103 \times \mathrm{Z} 11-0.034 \times \mathrm{Z} 12+0.155 \times \mathrm{Z} 13+0.028 \times \mathrm{Z} 14+0.101 \times \mathrm{Z} 15 \\
\mathrm{~F} 3=0.229 \times \mathrm{Z} 1+0.292 \times \mathrm{Z} 2-0.335 \times \mathrm{Z3}-0.216 \times \mathrm{Z} 4+0.012 \times \mathrm{Z} 5+0.137 \times \mathrm{Z} 6-0.016 \times \mathrm{Z} 7+0.121 \times \mathrm{Z} 8+0.121 \\
\times \mathrm{Z} 9-0.217 \times \mathrm{Z} 10+0.158 \times \mathrm{Z} 11-0.079 \times \mathrm{Z} 12+0.008 \times \mathrm{Z} 13-0.087 \times \mathrm{Z} 14-0.114 \times \mathrm{Z} 15
\end{array}
$$

By substituting the standardized data into the above formula, the scores of six samples for the three principal components

\begin{tabular}{|c|c|c|c|c|c|c|c|c|}
\hline & \multicolumn{4}{|c|}{ Component scoring coefficient } & \multirow[b]{2}{*}{ Components } & \multicolumn{3}{|c|}{ Eigenvalues of the correlation matrix } \\
\hline & Properties & f1 & $\mathrm{f} 2$ & f3 & & Eigenvalue & Proportion $\%$ & Cumulative $\%$ \\
\hline $\mathrm{Z1}$ & $\mathrm{HCO}_{3}^{-}$ & 0.163 & 0.022 & 0.034 & f1 & 6.420 & 42.801 & 42.801 \\
\hline $\mathrm{Z} 2$ & Nitrate-N & 0.156 & 0.089 & 0.050 & $\mathrm{f} 2$ & 5.102 & 34.015 & 76.817 \\
\hline $\mathrm{Z} 3$ & $\mathrm{SO}_{4}^{2-}$ & 0.144 & 0.044 & -0.099 & $\mathrm{f} 3$ & 2.253 & 15.018 & 91.834 \\
\hline $\mathrm{Z4}$ & AP & 0.131 & -0.068 & 0.238 & & & & \\
\hline $\mathrm{Z} 5$ & $\mathrm{~K}^{+}$ & 0.112 & -0.142 & 0.058 & & & & \\
\hline Z6 & Salinity & 0.044 & 0.241 & -0.097 & & & & \\
\hline $\mathrm{Z7}$ & SOM & 0.044 & 0.046 & 0.198 & & & & \\
\hline Z8 & $\mathrm{Na}^{+}$ & 0.043 & 0.241 & -0.097 & & & & \\
\hline Z9 & $\mathrm{pH}$ & 0.014 & 0.095 & -0.338 & & & & \\
\hline $\mathrm{Z} 10$ & AK & -0.041 & -0.066 & 0.304 & & & & \\
\hline Z11 & Ammonia-N & -0.044 & -0.197 & 0.012 & & & & \\
\hline $\mathrm{Z} 12$ & $\mathrm{Cl}^{-}$ & -0.060 & 0.166 & 0.001 & & & & \\
\hline $\mathrm{Z} 13$ & $\mathrm{Mg}^{2+}$ & -0.104 & 0.125 & -0.018 & & & & \\
\hline $\mathrm{Z} 14$ & $\mathrm{Ca}^{2+}$ & -0.161 & -0.052 & 0.146 & & & & \\
\hline $\mathrm{Z} 15$ & $\mathrm{EC}$ & -0.178 & -0.019 & -0.009 & & & & \\
\hline
\end{tabular}
could be obtained. In this study, the comprehensive fertility of six samples was represented by the comprehensive scores of PCA. The comprehensive score formula was $\mathrm{F}=0.43 \times \mathrm{F} 1+0.34 \times \mathrm{F} 2+0.15 \times \mathrm{F} 3$, and the coefficients are the principal component contribution rates. The principal component scores and the comprehensive scores of each sample are shown in Table 3.

Table 2. Principal component analysis of the chemical properties of sediment.

AP: Available P; SOM: soil organic matter; AK: available K; EC: electrical conductivity.

Table 3. Principal component scores and comprehensive scores of samples.

\begin{tabular}{lcrrc}
\hline Samples & F1 & F2 & F3 & Comprehensive scores \\
\hline S0 & -0.12713 & 1.59001 & 0.66130 & 0.585133 \\
S1 & -0.24588 & 0.79137 & -0.19104 & 0.134681 \\
S4 & 1.78421 & -0.38973 & 0.20062 & 0.664795 \\
S6 & 0.11665 & -0.23146 & -1.74199 & -0.289840 \\
S7 & -0.23516 & -1.09340 & 1.19805 & -0.293170 \\
S8 & -1.29270 & -0.66679 & -0.12694 & -0.801610 \\
\hline
\end{tabular}




\section{Analysis of the marine sediment bacteria}

This study used MiSeq (Illumina, San Diego, California, USA) sequencing to identify bacteria in the marine sediment and further analyzed the diversity of bacteria community. In this study, Shannon-Weiner index $(\mathrm{H})$, Pielou evenness index (J), Margalef richness index (d) and Simpson index (D) were also calculated to determine bacteria diversity. Redundancy analysis (RDA) was further used to evaluate the influence of the 15 chemical properties on bacteria in marine sediment during the $8 \mathrm{yr}$ of soil formation.

\section{Statistical analysis}

The software package SPSS 24.0 was used for statistical analyses, and SigmaPlot 12.5 (Systat Software, San Jose, California, USA) and R (R Foundation for Statistical Computing, Vienna, Austria) were used to generate figures. The rank-abundance curve, rarefaction curve, and RDA analysis were also completed using R statistical software.

\section{RESULTS}

\section{Change in chemical properties during the $8 \mathrm{yr}$ soil formation period}

As shown in Figure 2a and Table 4, the sediment maintained high salinity during the soil formation process. As soil formation progressed, both the electrical conductivity (EC) and salinity of the marine sediment initially increased and then decreased (Table 4, Figure $2 \mathrm{a}$ and $2 \mathrm{~b}$ ). Specifically, salinity increased slightly by $15.00 \%$ from S0 to S4 and then declined significantly by $69.00 \%$ from S4 to S8. EC increased by $61.39 \%$ from S0 to S4 and then decreased by $36.20 \%$

Figure 2. Salinity (a), electrical conductivity (EC) (b) and pH (c) changes of sediments during the soil-forming process.
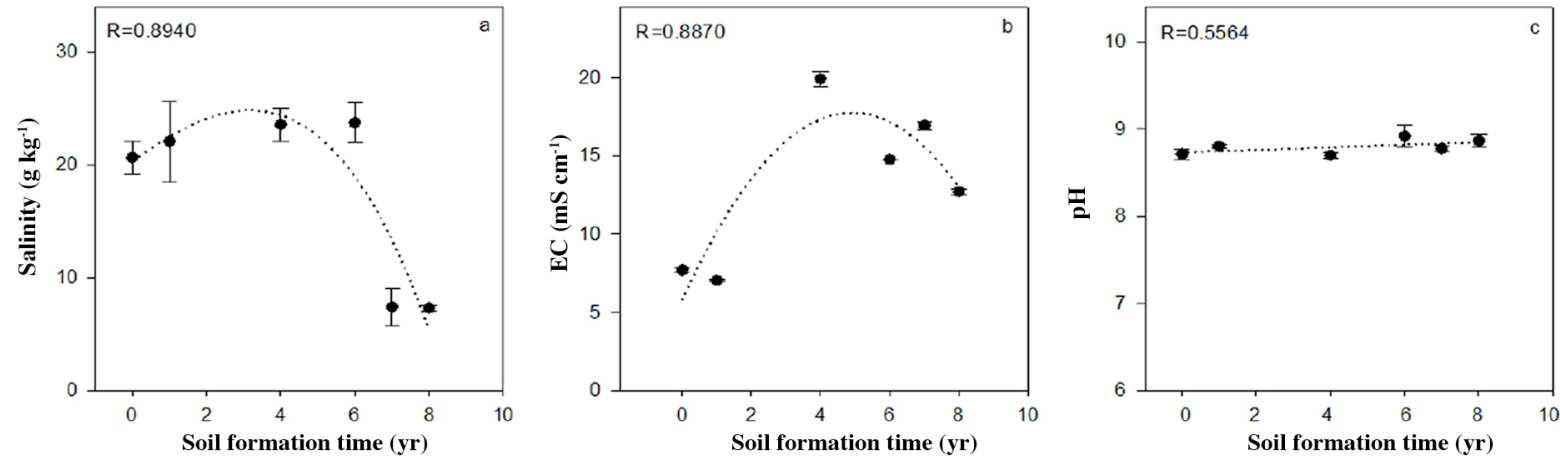

The R-value of each curve is shown in the top left corner of each figure. Vertical bars indicate \pm SE.

Table 4. Soil properties of cropland and sediments during the soil-forming process.

\begin{tabular}{lrrrrrrr}
\hline Soil properties & $\mathrm{S} 0$ & $\mathrm{~S} 1$ & $\mathrm{~S} 4$ & \multicolumn{1}{c}{$\mathrm{S} 6$} & \multicolumn{1}{c}{$\mathrm{S} 7$} & $\mathrm{~S} 8$ & Cropland \\
\hline $\mathrm{AP}, \mathrm{mg} \mathrm{kg}^{-1}$ & 13.00 & 11.07 & 7.27 & 6.27 & 8.90 & 7.03 & 17.39 \\
$\mathrm{AK}, \mathrm{g} \mathrm{kg}^{-1}$ & 1.19 & 1.15 & 1.39 & 0.77 & 1.17 & 0.79 & 469.55 \\
$\mathrm{pH}$ & 8.71 & 8.80 & 8.70 & 8.92 & 8.77 & 8.86 & 7.45 \\
$\mathrm{EC}, \mathrm{ms} \mathrm{cm}^{-1}$ & 7.68 & 7.02 & 19.89 & 14.75 & 16.93 & 12.69 & \\
$\mathrm{SOM}, \mathrm{g} \mathrm{kg}^{-1}$ & 14.30 & 11.45 & 13.49 & 11.08 & 10.90 & 10.55 & 23.60 \\
$\mathrm{Nitrate}-\mathrm{N}, \mathrm{mg} \mathrm{kg}^{-1}$ & 8.28 & 4.31 & 1.50 & 3.73 & 1.00 & 1.14 & 0.29 \\
$\mathrm{Ammonia}^{-\mathrm{N}}, \mathrm{mg} \mathrm{kg}^{-1}$ & 0.19 & 0.21 & 0.15 & 0.24 & 1.08 & 1.53 & 0.00 \\
$\mathrm{Ca}^{2+}, \mathrm{g} \mathrm{kg}^{-1}$ & 0.08 & 0.08 & 0.12 & 0.08 & 0.10 & 0.08 & 0.16 \\
$\mathrm{HCO}_{3}^{-}, \mathrm{g} \mathrm{kg}^{-1}$ & 0.51 & 0.49 & 0.44 & 0.44 & 0.42 & 0.49 & 0.03 \\
$\mathrm{Cl}^{-}, \mathrm{g} \mathrm{kg}^{-1}$ & 0.18 & 0.17 & 0.28 & 0.21 & 0.14 & 0.08 & 0.05 \\
$\mathrm{SO}_{4}^{2-}, \mathrm{g} \mathrm{kg}^{-1}$ & 0.23 & 0.21 & 0.17 & 0.20 & 0.16 & 0.25 & 0.11 \\
$\mathrm{Salinity}^{\mathrm{g}} \mathrm{g} \mathrm{kg}^{-1}$ & 20.64 & 22.07 & 23.56 & 23.72 & 7.39 & 7.30 & \\
$\mathrm{~K}^{+}, \mathrm{g} \mathrm{kg}^{-1}$ & 0.03 & 0.03 & 0.02 & 0.02 & 0.03 & 0.03 & 1.60 \\
$\mathrm{Na}^{+}, \mathrm{g} \mathrm{kg}^{-1}$ & 19.50 & 21.00 & 22.50 & 22.67 & 6.53 & 6.35 & 11.36 \\
$\mathrm{Mg}^{2+}, \mathrm{g} \mathrm{kg}^{-1}$ & 0.04 & 0.04 & 0.05 & 0.04 & 0.04 & 0.04 & 0.04 \\
\hline
\end{tabular}

AP: Available P; AK: available K; EC: electrical conductivity; SOM: soil organic matter. 
from S4 to S8. These results indicated that marine sediments were in a severe salinization state for the first 4 yr following introduction into the coastal land. The significant decline in salinity of the marine sediments from S4 to S8 indicated that the salinization degree of sediment had a negative trend in these years. In addition, the marine sediment was strongly alkaline during soil formation. As shown in Figure 2c and Table 4, $\mathrm{pH}$ values were 8.7-8.9 throughout the experiment and showed nonsignificant differences, indicating that alkalinity continued to inhibit soil formation throughout the $8 \mathrm{yr}$.

Figure 3 illustrates the change of different ions in the analyzed sediment during the $8 \mathrm{yr}$ soil formation period. According to Table 4 and Figure 3, $\mathrm{K}^{+}, \mathrm{HCO}_{3}{ }^{-}$, and $\mathrm{SO}_{4}{ }^{2-}$ contents in sediments were nonsignificantly different in different years $(p>0.05)$, while $\mathrm{Na}^{+}, \mathrm{Cl}, \mathrm{Ca}^{2+}$ and $\mathrm{Mg}^{2+}$ contents changed significantly $(p<0.05)$. Compared with $\mathrm{S} 0, \mathrm{Na}^{+}$, $\mathrm{Cl}, \mathrm{Mg}^{2+}$, and $\mathrm{Ca}^{2+}$ sediment contents in $\mathrm{S} 4$ increased by $3,0.1,0.014$, and $0.043 \mathrm{~g} \mathrm{~kg}^{-1}$, respectively. From S4 to S8, $\mathrm{Na}^{+}$

Figure 3. Water-soluble ion contents of marine sediments during soil-formation process and of cropland soil in the New Coastal Region of Tianjin.
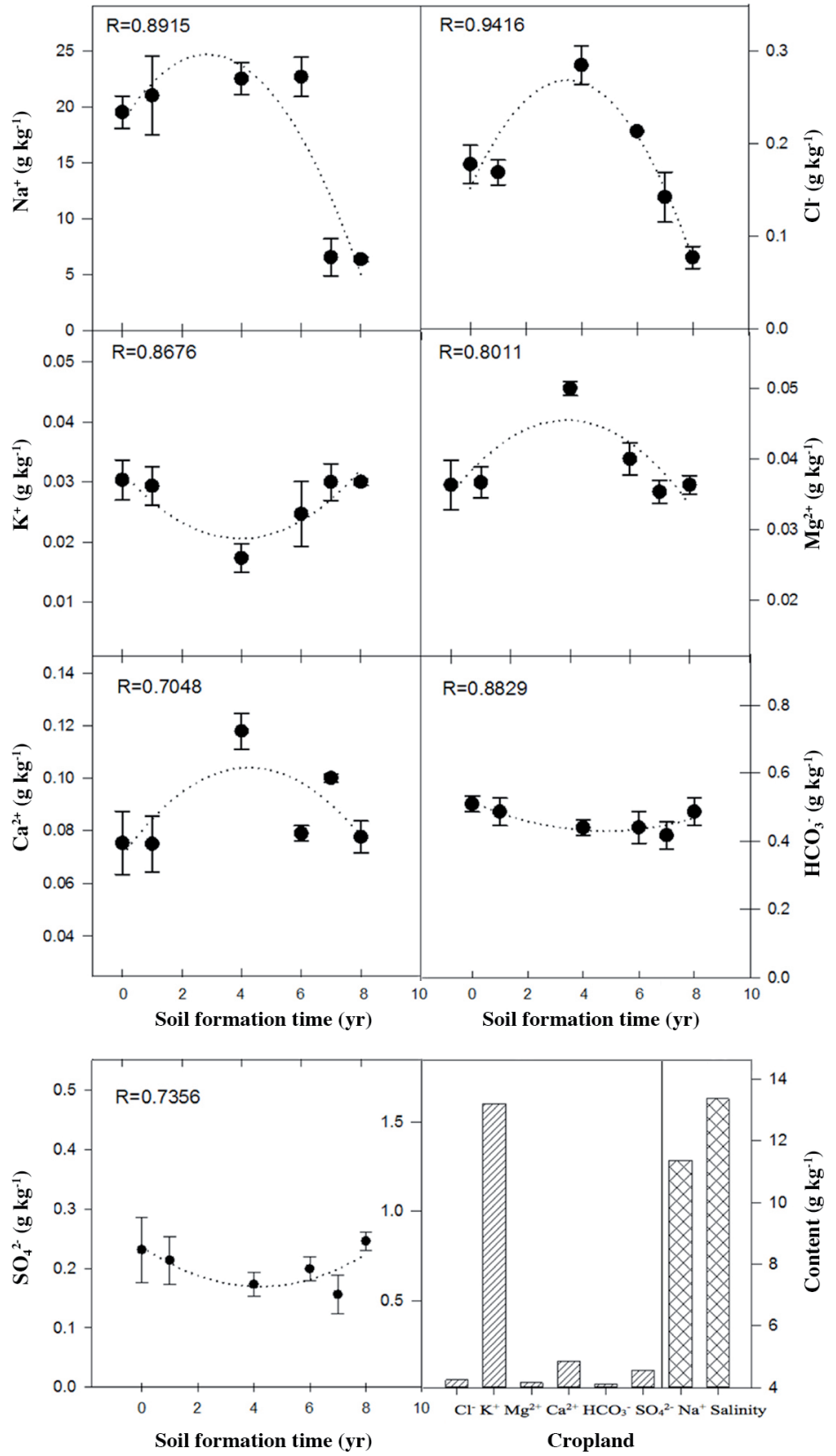

$\mathrm{R}$-value of each curve is shown in the top left corner of each figure. Vertical bars indicate $\pm \mathrm{SE}$. 
content declined significantly by $17 \mathrm{~g} \mathrm{~kg}^{-1}$. Compared with $\mathrm{S} 0, \mathrm{Na}^{+}, \mathrm{Cl}^{-}, \mathrm{Mg}^{2+}$, and $\mathrm{Ca}^{2+}$ sediment contents in $\mathrm{S} 8$ declined by $14,0.2,0.014$, and $0.04 \mathrm{~g} \mathrm{~kg}^{-1}$, respectively. In summary, $\mathrm{Na}^{+}$and $\mathrm{Cl}^{-}$contents showed a declining trend during the 8 yr soil formation period, whereas $\mathrm{Mg}^{2+}$ and $\mathrm{Ca}^{2+}$ contents remained stable.

Compared with the chemical properties of the cropland (Ma, 2011), the sediment salinity in S8 decreased to 7.3 $\mathrm{g} \mathrm{kg}^{-1}$, which was less than that of the cropland $\left(13.36 \mathrm{~g} \mathrm{~kg}^{-1}\right)$ in Tianjin New Coastal Region. Alternatively, the $\mathrm{pH}$ did nonsignificantly change during the soil formation process. Compared with the nearly neutral $\mathrm{pH}$ of the cropland (7.45), the $\mathrm{pH}$ value of $\mathrm{S} 8$ sediment was 8.86 , which was strongly alkaline. The $\mathrm{K}^{+}$content of the sediment did not change significantly in the soil-forming process and the mean value was approximately $0.03 \mathrm{~g} \mathrm{~kg}^{-1}$, far below that of cropland soil $\left(1.604 \mathrm{~g} \mathrm{~kg}^{-1}\right)$. The $\mathrm{Na}^{+}$content showed a decreasing trend and the minimum value was $7 \mathrm{~g} \mathrm{~kg}^{-1}$, less than that of cropland soil $\left(11.364 \mathrm{~g} \mathrm{~kg}^{-1}\right)$. The $\mathrm{Cl}^{-}$content of the sediment also showed a decreasing trend and the minimum value was 0.078 $\mathrm{g} \mathrm{kg}^{-1}$, slightly higher than that of the cropland $\left(0.053 \mathrm{~g} \mathrm{~kg}^{-1}\right)$; however, this difference narrowed with time. The average $\mathrm{Mg}^{2+}$ content of the sediment was $0.04 \mathrm{~g} \mathrm{~kg}^{-1}$ throughout the $8 \mathrm{yr}$, similar to that of the cropland $\left(0.037 \mathrm{~g} \mathrm{~kg}^{-1}\right)$. The Ca ${ }^{2+}$ content of the sediment was stable with a mean value of $0.08 \mathrm{~g} \mathrm{~kg}^{-1}$, lower than the cropland value $\left(0.16 \mathrm{~g} \mathrm{~kg}^{-1}\right)$. The $\mathrm{HCO}_{3}$ content of the sediment did not change significantly throughout the soil formation process and the mean value was 0.44 $\mathrm{g} \mathrm{kg}^{-1}$, higher than that of the cropland soil $\left(0.029 \mathrm{~g} \mathrm{~kg}^{-1}\right)$. The $\mathrm{SO}_{4}{ }^{2-}$ content of the sediment did not change significantly throughout the soil formation process and the mean value was $0.2 \mathrm{~g} \mathrm{~kg}^{-1}$, higher than that of the cropland $\left(0.108 \mathrm{~g} \mathrm{~kg}^{-1}\right)$. In summary, the $\mathrm{Ca}^{2+}, \mathrm{HCO}_{3}{ }^{-}$, and the $\mathrm{SO}_{4}{ }^{2-}$ contents were not improved under natural conditions and had a negative impact on soil formation, indicating that the soil urgently requires artificial improvement. The natural changes in salinity, $\mathrm{Na}^{+}$ and $\mathrm{Mg}^{2+}$ contents positively influenced soil formation. In addition, the results indicated that measures should be taken to reduce the $\mathrm{pH}$ of the marine sediment.

\section{Change in effective soil nutrients during the $8 \mathrm{yr}$ soil formation period}

As shown in Figure 4 and Table 4, the soil organic matter (SOM), available P (AP), available K (AK), and nitrate-N contents of the marine sediment reduced linearly with increased time, while the content of ammonia-N initially showed a stable trend and then increased significantly. Compared with $\mathrm{S} 0$, the SOM, AP, AK, and nitrate-N contents of the marine sediment at S8 reduced by $26.22 \%, 45.92 \%, 33.61 \%$, and $86.23 \%$, respectively. The ammonia-N content was maintained from S0 to S6 and then increased by $84.31 \%$, from 0.24 (S6) to $1.53 \mathrm{mg} \mathrm{kg}^{-1}$ (S8). As soil formation progressed, the nitrate- $\mathrm{N}$ content decreased while the ammonia- $\mathrm{N}$ content increased (Figure $4 \mathrm{~d}$ and e), indicating that some nitrate- $\mathrm{N}$ might be converted into ammonia- $\mathrm{N}$. The total inorganic $\mathrm{N}$ content showed a downward trend.

Compared with the cropland (Ma, 2011), the maximum SOM content of the sediment was $14.30 \mathrm{~g} \mathrm{~kg}^{-1}$ (S0), which is less than that of the cropland soil $\left(23.6 \mathrm{~g} \mathrm{~kg}^{-1}\right)$. The AK content of the sediment during the $8 \mathrm{yr}$ soil formation period was 0.77 to $1.39 \mathrm{mg} \mathrm{kg}^{-1}$, which was higher than that in the cropland $\left(0.47 \mathrm{mg} \mathrm{kg}^{-1}\right)$. As for nitrate- $\mathrm{N}$, the content decreased as soil formation progressed and reached a minimum in S8 (1.14 $\left.\mathrm{mg} \mathrm{kg}^{-1}\right)$, much lower than that of the cropland soil (290 $\mathrm{mg} \mathrm{kg}^{-1}$ ). Nitrate-N would be more suitable for artificial improvement due to this large difference in nitrate-N content between cropland soil and marine sediment. The maximum content of ammonia- $\mathrm{N}$ was $1.53 \mathrm{mg} \mathrm{kg}^{-1}$, lower than that of the cropland soil ( $\left.4.5 \mathrm{mg} \mathrm{kg}^{-1}\right)$, but it increased naturally with time. Overall, apart from the change in ammonia-N content, which was favorable to soil formation, the loss of other effective nutrients was severe during these $8 \mathrm{yr}$.

Figure 5 and Table 3 illustrates the comprehensive fertility of the sediment during the $8 \mathrm{yr}$ soil formation period. The comprehensive fertility of the sediment showed a downward trend, indicating that the loss of soil fertility was severe. This result was consistent with the above results and further verified the serious fertility loss in the process of soil formation over the 8 yr under study.

\section{Change in bacterial community diversity after sediments entered the coastal land for $\mathbf{8} \mathbf{~ y r}$}

In this study, for the two samples (S0 and S8), we calculated the diversity of the bacteria at the class, order, family, and genera levels using diversity indexes (Shannon-Wiener, Simpson, evenness, and richness) and the results are summarized in Figure 6. S0 sediment had a higher Shannon-Wiener and Pielou evenness index at all four levels than S8, indicating that bacteria diversity declined after sediment entered the coastal land over 8 yr. Simpson index was higher in the S8 sample for order, family, and genera. As for Margalef richness index, S8 was higher than S0 at all four levels, indicating that species abundance in the S8 sample was higher than that of S0, which was consistent with the rank-abundance curve in 
Figure 7. As shown in Figure 7, the slope of S0 was gentler than that of S8; therefore, the evenness of S0 was higher than that of S8. The richness index showed that the total number of bacteria significantly rose after the sediment was extracted from sea to land during the 8 yr period (Figure 8), which was consistent with Figure 6D. Moreover, the species of bacteria increased significantly in S8 (Figure 9). Eight years later, 486 bacterial species disappeared, 1595 foreign bacteria species entered this system and 811 bacteria species survived; moreover, the number of new bacteria species was greater than the number of species which disappeared (Figure 9). In summary, after $8 \mathrm{yr}$ of soil formation, the overall abundance of bacteria communities increased significantly, while the community diversity decreased at the class, order, family, and genera levels.

Figure 4. Effective nutrients of marine sediments during soil-formation process and of cropland soil in the New Coastal Region of Tianjin.
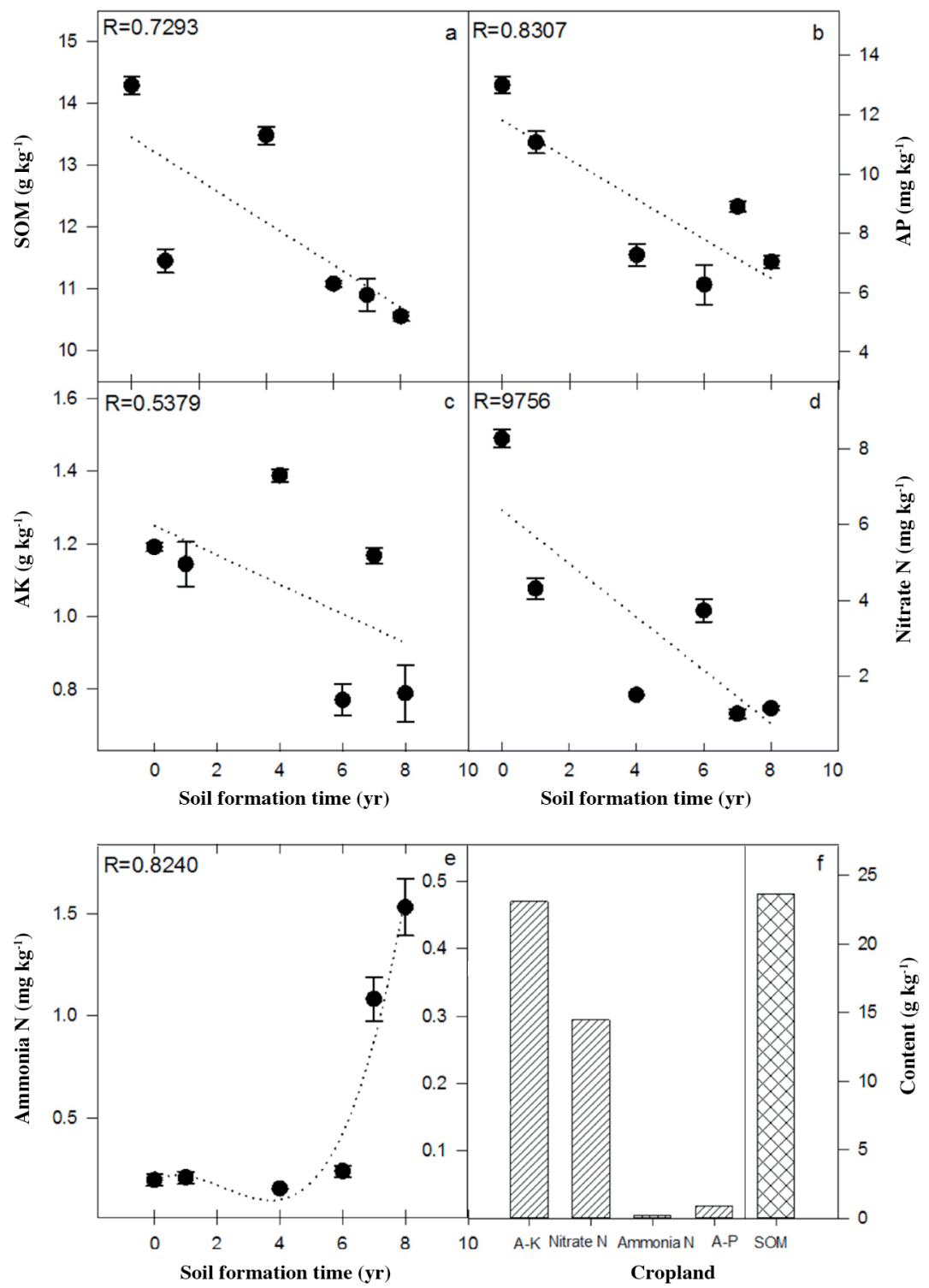

R-value of every curve is shown in the top left corner of figure. Vertical bars indicate mean $\pm \mathrm{SE}$. SOM: Soil organic matter; AK: available K; AP: available P. 
Figure 5. Changes in sediment fertility during soil formation.

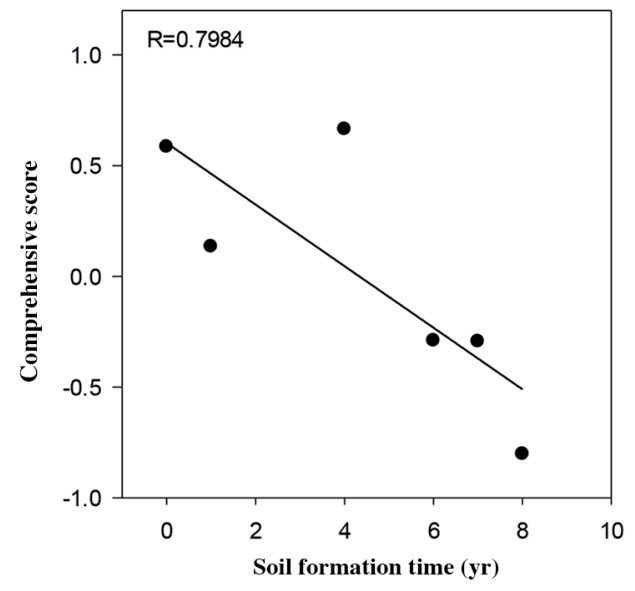

Figure 6. Differences in bacteria diversity indexes at different taxonomical hierarchies after marine sediment entered the terrestrial environment for zero years (S0) and 8 yr (S8).
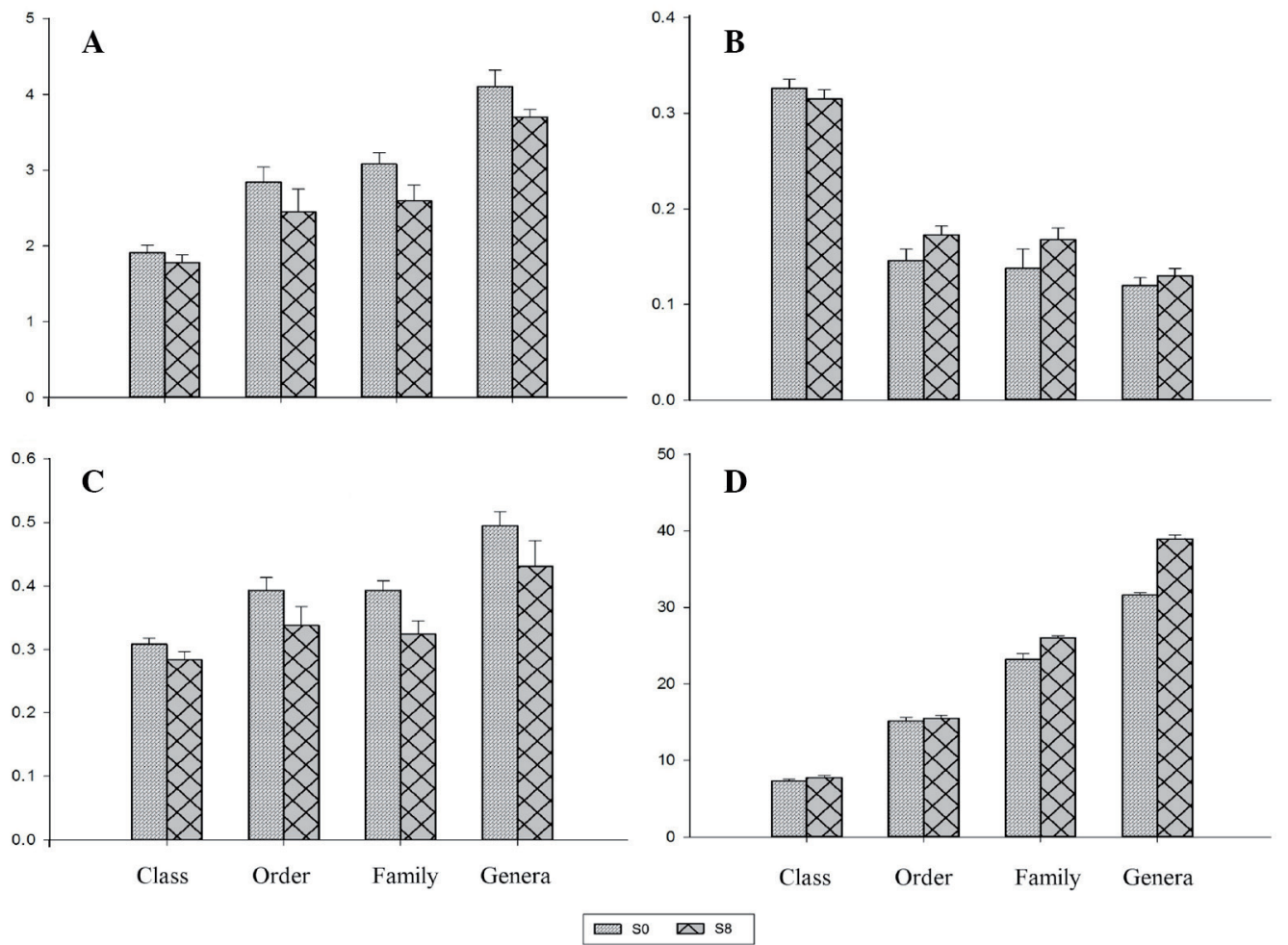

A: Shannon Wiener index; B: Simpson index; C: Evenness index; D: Richness index. 
Figure 7. Rank-abundance curve depicting bacteria community differences in the marine sediments after marine sediment entered the terrestrial environment for zero years (S0) and 8 yr (S8).

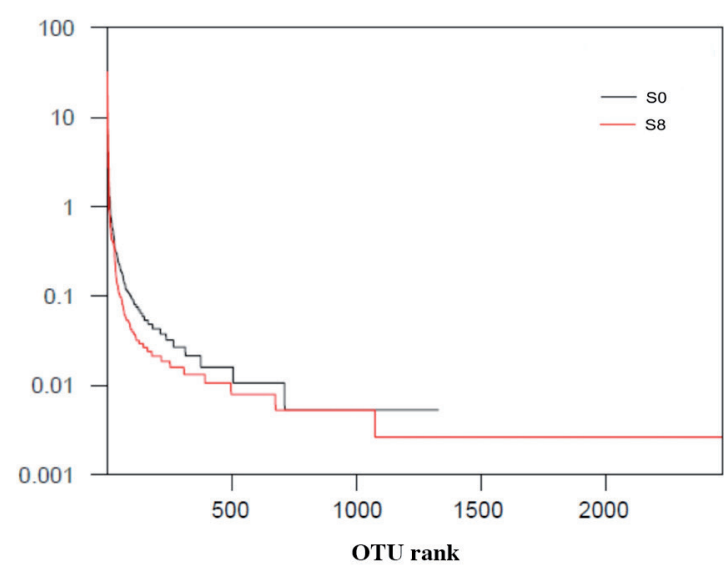

OTU: Operational taxonomic units.

Figure 8. Rarefaction curve representing differences in the bacteria community after marine sediment entered the terrestrial environment for zero years (S0) and $8 \mathrm{yr}$ (S8).

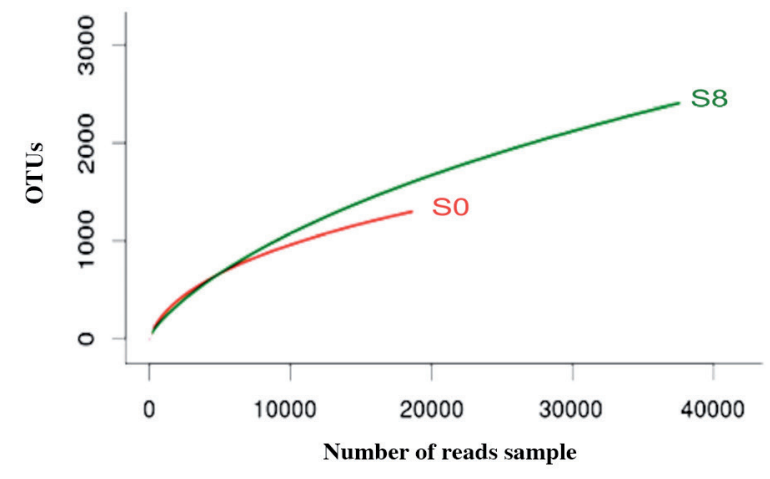

OTU: Operational taxonomic units.

Figure 9. Venn diagram representing OTU distribution after marine sediment entered the terrestrial environment for zero years (S0) and 8 yr (S8).

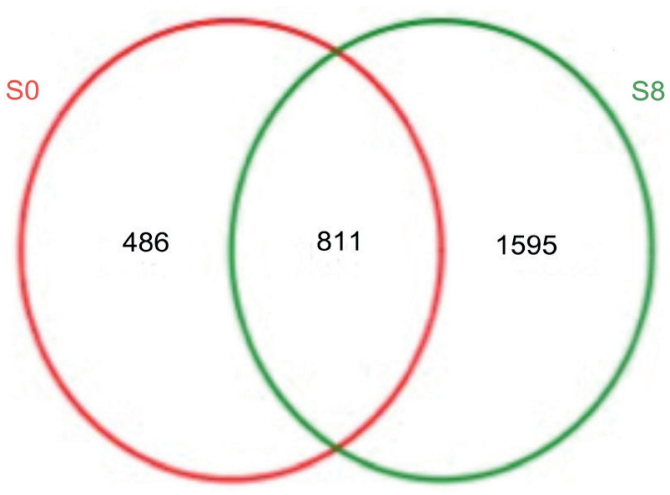

OTU: Operational taxonomic units. 


\section{Change of dominant genera after sediments entered the coastal land for $8 \mathrm{yr}$}

There were 342 bacteria genera detected by MiSeq sequencing. There were 12 major bacterial genera in S0 and their relative abundance were as follows (Figure 10): Thiomicrospira (33.68\%), Pseudomonas (5.95\%), Lactococcus (5.86\%), Sulfurimonas (5.54\%), Psychromonas (3.62\%), Sva1033_norank (3.53\%), JTB255_marine_benthic_group_norank (2.8\%), Fusibacter (2.62\%), Desulfobulbus (1.96\%), Colwellia (1.9\%), Lutibacter (1.76\%) and Marinobacter (1.33\%). S8 had 8 dominant genera: Thiomicrospira (32.15\%), Planomicrobium (15.96\%), Psychrobacter (10.61\%), Salegentibacter (9.15\%), Gillisia (3.04\%), Marinobacter (1.97\%), Halomonas (1.39\%), and Sulfurimonas (1.11\%). The major bacterial phyla identified among the two samples included, Proteobacteria (S0: 73.70\%; S8: 55.72\%), Firmicutes (S0: 10.63\%; S8: 18.51\%), Bacteroidetes (S0: 4.35\%; S8: 14.95\%), Chloroflexi (S0: 3.50\%; S8: 2.05\%), and Actinobacteria (S0: 2.32\%; S8: $5.21 \%)$.

Thiomicrospira, Marinobacter, and Sulfurimonas were the most common genera in the two samples. Compared with S0, the relative abundance of Thiomicrospira and Marinobacter in S8 did not changed significantly, while Sulfurimonas decreased by $4.43 \%$. In addition, the abundance of genera differed before and after the marine sediment entered the coastal land (Figure 10). After $8 \mathrm{yr}$, the abundances of many genera declined in the marine sediment: Sulfurimonas, Lutibacter, Sva1033_norank, Psychromonas, Pseudomonas, JTB255_marine_benthic_group_norank, Desulfobulbus, Lactococcus, Fusibacter and Colwellia, which decreased by 0.61-fold, 0.65-fold, 0.70-fold, 0.73-fold, 0.70-fold, 0.84fold, 0.87 -fold, 0.88 -fold, 0.89 -fold and 0.95 -fold, respectively. The abundances of other genera rose significantly: Psychrobacter, Planomicrobium, Gillisia, Salegentibacter, and Halomonas, which increased by 42.90-fold, 46.17-fold, 42.90-fold, 125.18-fold and 315.5-fold, respectively.

In addition to the above-mentioned bacteria genera, some new bacteria genera entered the sediments and survived during the $8 \mathrm{yr}$ soil formation process. Moreover, according to the taxonomic data of this study, 117 genera of bacteria were alien species, including: Algoriphagus, Blastopirellula, Haliangium, Ilumatobacter, Methylophaga, Microbulbifer, Muricauda, Phycisphaera, S0134_terrestrial_group_norank, Arenibacter, Jeotgalibacillus, and Lewinella. Meanwhile, 46 native bacteria genera disappeared, including: Bacteroides, Carnobacterium, Desulfocapsa, KI89A_clade_norank, Lactobacillus, Nitrospina, SS1-B-09-64_norank, and pItb-vmat-80_norank.

\section{Relationship between sediment properties and bacterial communities}

In this study, RDA was used to analyze the relationship between the change in chemical properties and the change in bacterial communities in marine sediments. The eigenvalues of the first and second ordination axes are 163.332 and 1.453, respectively, which explained $99 \%$ and $0.8 \%$ of bacterial community variations, respectively. The cumulative proportion was $99.8 \%$, meaning that the first two axes can reflect the correlation between bacterial community and physical and chemical soil properties, but it was primarily determined by the first ordination axis. A two-dimensional ordination figure can then be obtained (Figure 11).

Figure 10. Differences among the dominant bacteria genera in sediments after marine sediment entered the terrestrial environment for zero years (S0) and $8 \mathrm{yr}$ (S8).
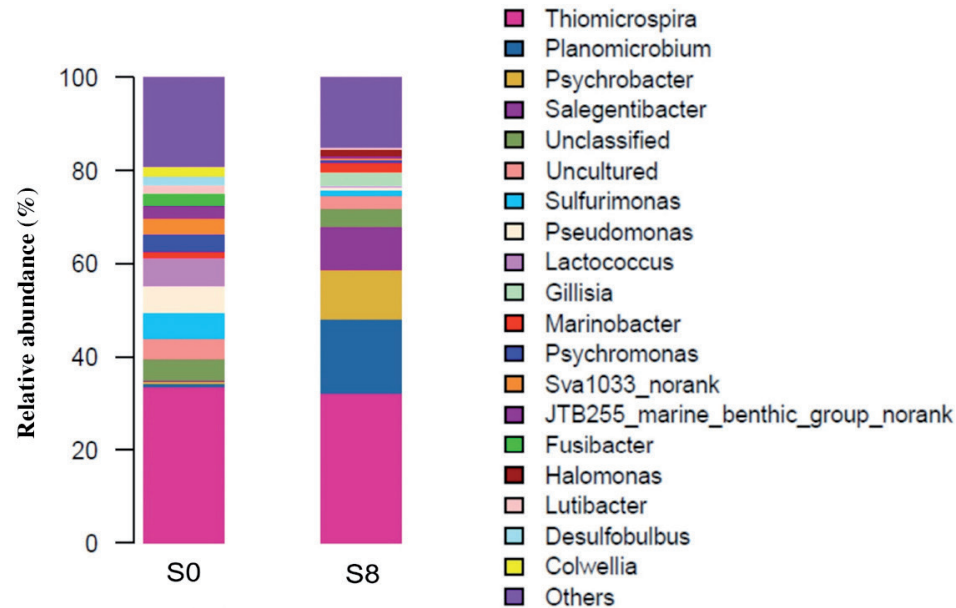
Figure 11. Redundancy analysis (RDA) ordination depicting the relationship between sediment properties and the bacteria community at the genera level.

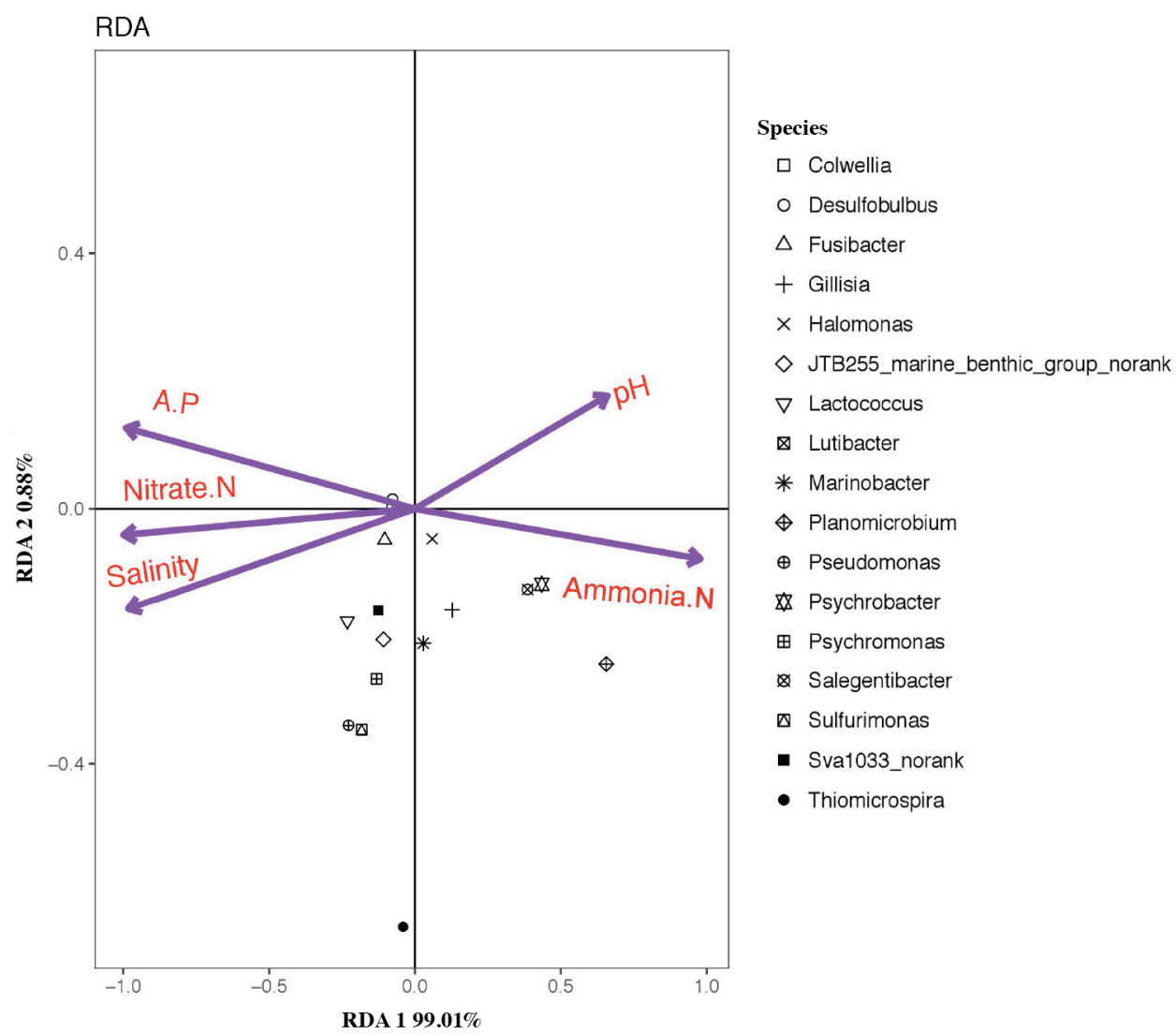

AP: Soil available P.

As shown in Figure 11, the relative abundances of Thionicrospira, Sulfurimonas, Lutibacter, Sva1033_norank, Psychromonas, Pseudomonas, JTB255_marine_benthic_group_norank, Desulfobulbus, Lactococcus, Fusibacter, and Colwellia showed a positive correlation with soil contents (AP, nitrate-N, $\mathrm{Na}^{+}, \mathrm{Cl}^{-}$and salinity), but showed a negative correlation with $\mathrm{pH}$ and ammonia-N contents. The relative abundances of Psychrobacter, Planomicrobium, Gillisia, Salegentibacter, Marinobacter, and Halomonas had a positive correlation with $\mathrm{pH}$ and the ammonia-N content, but showed a negative correlation with $\mathrm{AP}$, nitrate- $\mathrm{N}, \mathrm{Na}^{+}, \mathrm{Cl}^{-}$, and salinity contents. According to Figures 2 and 3 , compared with S0, AP, nitrate- $\mathrm{N}, \mathrm{Na}^{+}, \mathrm{Cl}^{-}$, and salinity contents in marine sediments decreased, while $\mathrm{pH}$ and ammonia- $\mathrm{N}$ content increased after 8 yr (S8). The change in bacteria genera abundances corresponded to this trend seen in Figure 11.

These soil properties explained $99.8 \%$ of total eigenvalues, indicating that soil properties had a significant effect on the structure of the bacterial community in the marine sediment. According to Table 5, AP, nitrate- $\mathrm{N}$, salinity, $\mathrm{Na}^{+}$, and $\mathrm{Cl}^{-}$are the main environmental factors influencing the quantity and community structure of sediment bacteria. 
Table 5. Correlations between environmental factors and the ordination axis.

\begin{tabular}{lccc}
\hline Soil properties & Axis1 & Axis2 & Variance explain \\
\hline $\mathrm{AP}$ & -0.99192 & 0.126886 & $0.996^{* *}$ \\
$\mathrm{Nitrate}-\mathrm{N}$ & -0.99916 & -0.040868 & $0.9999^{* *}$ \\
Salinity & -0.98742 & -0.158122 & $0.9904^{* *}$ \\
$\mathrm{Na}^{+}$ & -0.98705 & -0.16044 & $0.9918^{* *}$ \\
$\mathrm{Cl}^{-}$ & -0.96822 & -0.2501 & $0.8987^{*}$ \\
$\mathrm{Mg}^{2+}$ & -0.04722 & -0.99888 & 0.5165 \\
$\mathrm{pH}$ & 0.9658 & 0.259298 & 0.4661 \\
$\mathrm{EC}$ & 1 & -0.001788 & 0.9869 \\
$\mathrm{AK}$ & -0.99622 & 0.12689 & 0.996 \\
$\mathrm{SOM}$ & -0.99962 & -0.02774 & 0.9935 \\
$\mathrm{Ammonia}-\mathrm{N}$ & 0.99681 & -0.07987 & 0.9635 \\
$\mathrm{Ca}{ }^{2+}$ & 0.41422 & -0.91018 & 0.0403 \\
$\mathrm{HCO}_{3}^{-}$ & -0.81032 & 0.58599 & 0.0403 \\
$\mathrm{SO}_{4}{ }^{-}$ & 0.53281 & 0.84623 & 0.0618 \\
$\mathrm{~K}^{+}$ & -0.09252 & -0.99571 & 0.6614 \\
\hline
\end{tabular}

AP: Available P; EC: electrical conductivity; AK: available K; SOM: soil organic matter.

"Significant correlation between soil properties and nematodes $(p<0.05)$

${ }^{*}$ Significant correlation between soil properties and nematodes $(p<0.01)$.

\section{DISCUSSION}

\section{Effects of bacterial community on marine sediment properties during the $8 \mathrm{yr}$ soil formation process}

In this study, as soil formation progressed, the overall abundance of bacterial communities increased significantly at the class, order, family, and genera levels. For example, compared with S0, the abundance of Planomicrobium and Halomonas at S8 increased significantly. Both of these genera are comprised of denitrifying bacteria (DNB) species. DNB can produce a series of products using nitrate as the final electron acceptor including, $\mathrm{NO}^{2-}, \mathrm{NO}, \mathrm{N}_{2} \mathrm{O}$, and $\mathrm{N}_{2}$ (Zumft, 1997). Therefore, the increase of DNB may have contributed to the decrease of nitrate-N during the $8 \mathrm{yr}$ soil formation period. For crops and other plants, nitrate- $\mathrm{N}$ is the main source of $\mathrm{N}$, and the absorption rate of nitrate- $\mathrm{N}$ by plants is higher than that of ammonia-N. Therefore, for marine sediment in Tianjin Port, the loss of nitrate-N and the increase of ammonia-N likely contributed most to this area being void of plants. In addition, Sulfurimonas and Psychromonas are nitrate-reducing bacteria (NRB), which can utilize $\mathrm{NO}^{2-}$ and $\mathrm{NO}^{3-}$ as the final electron acceptor for respiration, and thus, reduce nitrate to nitrite (Tan et al., 2007). However, their abundances decreased over time. After the sediments were separated from the seawater and added to the land, there was almost no exogenous nitrate-N input. It is likely that NRB initially increased in number and consumed nitrate- $\mathrm{N}$, resulting in a decrease in nitrate- $\mathrm{N}$ and in turn causing an associated decline in NRB.

Desulfobulbus and Fusibacter are sulfate-reducing bacteria (SRB). They can use sulfate or other oxidation state sulfide as electron receptors to produce organic substances and can be found in water and sediment (Guo et al., 2016). Zumft (1997) found that $\mathrm{N}_{2} \mathrm{O}$ can increase the output of redox potential within a limited space, which in turn can limit the growth of SRB considering that these bacteria have a strict demand for redox potential. In addition, under the same conditions, the denitrification response ability of microbial organisms is stronger than their sulfate reduction reaction ability. Moreover, under the same $\mathrm{C}$ source conditions, the denitrification rate of microorganisms is more than twice the rate of sulfate reduction. Furthermore, compared with SRB, DNB occupy a dominant position in the competing matrix (Chidthaisong and Conrad, 2000). In summary, the growth of sulfate reducing bacteria is likely inhibited by denitrifying bacteria. Therefore, in the present study, the increase in Planomicrobium and Halomonas abundances may have caused the decline in Desulfobulbus and Fusibacter abundances, likely due to competitive inhibition. It can also explain why the $\mathrm{SO}_{4}{ }^{2-}$ content did nonsignificantly change during the $8 \mathrm{yr}$ soil formation period.

\section{Effects of marine sediment properties on the bacterial community during the $8 \mathrm{yr}$ soil formation period}

In this study, results showed that after $8 \mathrm{yr}$, bacterial community abundances increased significantly while bacterial community diversity declined. Additionally, the structure of bacterial community changed: the Proteobacteria abundances significantly decreased while Firmicutes, Bacteroidetes, and Actinobacteria abundances increased significantly after 
sediment entered the coastal land for 8 yr. According to previous studies conducted on the Dalian Changshan Islands ( $\mathrm{Li}$ et al., 2011), Beidaihe (Fan et al., 2008), Qingdao, Weihai (Xiao et al., 2009), Lianyungang (Zhu, 2009) and Cangnan bay (Huo et al., 2008), these bacteria phyla were the dominant microbes of offshore sediments along the Chinese coastline, which was consistent with the results of our study.

Jin (2013) suggested that high salinity is one of main factors restricting the improvement and utilization of marine sediment for land reclamation. Generally, in the marine environment, seawater salt is mainly composed of $\mathrm{Na}^{+}$and $\mathrm{Cl}^{-}$. In this study, $\mathrm{Na}^{+}$and $\mathrm{Cl}^{-}$contents were the main ions of salinity and showed the most significant change over time (Figures 2 and 3), which was consistent with the marine characteristics of the sediment. Specifically, the salinity of the sediment gradually decreased as soil formation progressed and this decline was less than that of the nearby cropland. This result indicates that the sediment retained high salinity in the initial stages of soil formation. However, the decrease of salinity had a positive impact on soil formation, which was consistent with Liu et al. (2010b). In addition, the total abundance of bacteria increased with the decrease of salinity, while bacterial community diversity decreased significantly. These results are consistent with Jackson and Vallaire (2009). These researchers also found that salinity depressed the function of sediment bacteria and thus changed the bacteria community composition. Ikenaga et al. (2010) further suggested that bacterial communities have different compositions and structures along the salinity gradient.

$\mathrm{pH}$ can also affect bacterial community structure and diversity in marine sediments (Rousk et al., 2010). Xiong et al. (2012) further found that $\mathrm{pH}$ regulated the structure of bacteria community more than salinity. Moreover, $\mathrm{pH}$ is the best predictor of bacterial community structure in alkaline sediments. For example, sediment with a higher $\mathrm{pH}$ positively influenced the growth of Alpha Proteobacteria (Chu et al., 2010; Rousk et al., 2010).

As for the relationship between nutrients and the quantity of bacteria, it was reported that due to the long-term use of pesticide and fertilizer in agricultural activities and oil pipeline leakage, petroleum and pesticide pollution is prevalent in Tianjin coastal waters (Wu et al., 2007). Pseudomonas and Colwellia can be used as degradation bacteria to aid in the reduction of these pollutants. These bacteria are highly abundant in marine and submarine sediments and they are often the dominant bacteria. We hypothesized that Pseudomonas and Colwellia constantly consumed oil and pesticide pollution in Tianjin Port. Then, without nutrient input from the seawater and as soil formation progressed, these bacteria were living in a nutrient-poor environment (compared to marine sediments), which in turn may have contributed to their abundance decline and their becoming less dominant bacterial strains in the terrestrial environment.

\section{CONCLUSIONS}

The marine sediment changed from severe to mild salinization during $8 \mathrm{yr}$ of soil formation. However, the $\mathrm{pH}$ value of the sediment was $>8.5$ and did not change significantly during the study period. In addition, sediment fertility decreased significantly and the total fertility loss was severe, especially the loss of nitrate-N.

Through MiSeq sequencing technology, we analyzed two soil-sediment samples: fresh marine sediment and marine sediment which entered the coastal land over the course of eight years. The results indicated that the abundance of bacteria increased significantly, while bacterial community diversity declined after $8 \mathrm{yr}$. Moreover, the composition of the bacterial community changed significantly.

There was an interaction between soil properties and bacterial communities. The results of redundancy analysis indicated that the bacterial community of the sediments was mainly affected by the following chemical properties: $\mathrm{pH}$, soil contents (available $\mathrm{P}$, nitrate- $\mathrm{N}$, ammonia- $\mathrm{N}, \mathrm{Na}^{+}, \mathrm{Cl}^{-}$) and salinity.

\section{ACKNOWLEDGEMENTS}

The study was supported by grants from National Natural Science Foundation of China $(31770499,31500365)$, the National Key Technology Research and Development Program of the Ministry of Science and Technology of China (2012BAD13B02), the Key Technology Research and Development Program of Tianjin (15ZCZDSF00410), the National Science Foundation of Tianjin (18JCYBJC96500). Xin Sui, Huijun Gu and Meiqing Jia contributed equally to this study and share first authorship. 


\section{REFERENCES}

Abbas, S.Z., Rafatullah, M., Ismail, N., and Syakir, M.I. 2017. A review on sediment microbial fuel cells as a new source of sustainable energy and heavy metal remediation: mechanisms and future prospective. International Journal of Energy Research 41(9):1242-1264.

Bao, S.D., 2000. Soil agrochemical analysis. $3^{\text {rd }}$ ed. China Agriculture Press, Beijing, China.

Chen, C., Liu, Q., Liu, C., and Yu, J. 2017. Effect of different enrichment strategies on microbial community structure in petroleum-contaminated marine sediment in Dalian, China. Marine Pollution Bulletin 117:1-2.

Chidthaisong, A., and Conrad, R. 2000. Turnover of glucose and acetate coupled to reduction of nitrate, ferric iron and sulfate and to methanogenesis in anoxic rice field soil. FEMS Microbiology Ecology 31(1):73-86.

Chu, H.Y., Fierer, N., Lauber, C.L., Caporaso, J.G., Knight, R., and Grogan, P. 2010. Soil bacterial diversity in the Arctic is not fundamentally different from that found in other biomes. Environmental Microbiology 12:2998-3006.

Du, Z.W., Li, H.R., and Gu, T.Y. 2007. A state of the art review on microbial fuel cells: A promising technology for wastewater treatment and bioenergy. Biotechnology Advances 25:464-482.

Fan, J.F., Zhang, L., Ming, H.X., Chen, L.G., Wu, L.J., Lin, F.A., et al. 2008. PCR-RFLP analysis of bacteria16S rDNA in marine sediment of Beidaihe. Marine Environmental Science 27:409-414.

Guo, H.Y., Yan, C., and Ling, G.M. 2005. Research on improving engineering properties of dredger fill with additive. Port Engineering Technology 01:50-51.

Guo, J., Zhao, L., Lu, W., Jia, H., and Sun, Y. 2016. Bacterial communities in water and sediment shaped by paper mill pollution and indicated bacterial taxa in sediment in Daling River. Ecological Indicators 60:766-773.

Gupta, K., Chatterjee, C., and Gupta, B. 2012. Isolation and characterization of heavy metal tolerant gram-positive bacteria with bioremedial properties from municipal waste rich soil of Kestopur canal (Kolkata), West Bengal, India. Biologia 67(5):827-836.

Huo, Y.Y., Xu, X.W., Wang, C.S., Yang, J.Y., and Wu, U. 2008. Bacterial diversity of the sediment from Cangnan large fishing bay. Acta Ecologica Sinica 28(10):5166-5172.

Ikenaga, M., Guevara, R., Dean, A.L., Pisani, C., and Boyer, J.N. 2010. Changes in community structure of sediment bacteria along the Florida Coastal Everglades marsh-mangrove-seagrass salinity gradient. Microbial Ecology 59(2):284-295.

Jackson, C.R., and Vallaire, S.C. 2009. Effects of salinity and nutrients on microbial assemblages in Louisiana wetland sediments. Wetlands 29(1):277-287.

Jin, C. 2013. Physico-chemical properties and soil envelopment by mixing sand research on dredger fill in Tianjin. Tianjin University of Technology, Tianjin, China.

Jolliffe, I.T. 1986. Principal component analysis. Springer, New York, USA.

Li, B., Du, M., Zhou, J., Liu, S., Xu, H., and Agron, D. 1992. The application of principal component analysis on the fertility evaluation of "Chao" soil. Journal of Agricultural University of Hebei 3:28-32.

Li, J., Wang, Z., Qin, S., and Wang, G. 2011. Microbial diversity of sediments from the coasts of Dalian Changshan Islands. Acta Microbiologica Sinica 51(5):656-666.

Liu, X.J., Shi, L., Su, J.X., and Zhang, X.Y. 2010a. Study on soil fertility decline of Pinus kesiya var. langbianensis with principal component analysis. Journal of Anhui Agricultural Sciences 38(19):10362-10363.

Liu, Y.J., Xu, J.Q., Wang, S., Tian, X.Y., Ren, D.M., and Li, G.N. 2010b. Influence on soil salinity and physiological characteristic of 3 plants with integrative technique of saline-alkali improvement in Yingkou coastal industrial base. Journal of Shenyang Agricultural University 41(3):354-356.

Logan, B.E., and Regan, J.M. 2006. Microbial fuel cells - challenges and applications. Environmental Science \& Technology 40:5172-5180.

Ma, W.M. 2011. The relationship between soil physical-chemical characteristics and quality of Coastal Plain. Northwest A\&F University, Yangling, Shaanxi, China.

Mincer, T.J., Jensen, P.R., and Fenical, W. 2002. Widespread and persistent populations of a major new marine actinomycete taxon in ocean sediments. Applied and Environmental Microbiology 68:5005-5011.

Mohanty, G., and Mukherji, S. 2008. Biodegradation rate of diesel range $n$-alkanes by bacterial cultures Exiguobacterium aurantiacum and Burkholderia cepacia. International Biodeterioration \& Biodegradation 61(3):240-250.

Moran, M.A. 2015. The global ocean microbiome. Science 350:aac845.

Okeke, B.C. 2008. Bioremoval of hexavalent chromium from water by a salt tolerant bacterium, Exiguobacterium sp. GS1. Journal of Industrial Microbiology \& Biotechnology 35(12):1571-1579.

Qin, Z., Tang, J., Cao, J., Wang, H., Deng, X., and Pan, B. 2015. Assessment of soil fertility of continuous plantation of Chinese fir based on principal component and cluster analysis. Forest Resources Management 5:81-87.

Romano, G., Costantini, M., Sansone, C., Lauritano, C., Ruocco, N., and Ianora, A. 2017. Marine microorganisms as a promising and sustainable source of bioactive molecules. Marine Environmental Research 128:58-69.

Rousk, J., Baath, E., Brookes, P.C., Lauber, C.L., Lozupone, C., Caporaso, J.G., et al. 2010. Soil bacterial and fungal communities across a pH gradient in an arable soil. ISME Journal 4:1340-1351. 
Sogin, M.L., Morrison, H.G., and Huber, J.A. 2006. Microbial diversity in the deep sea and the underexplored "rare biosphere". Proceedings of the National Academy of Sciences of the United States of America 103:12115-12120.

Sui, F.G., and Li, J.L. 2004. Soil agrochemical analysis experiment. $2^{\text {nd }}$ ed. Laiyang Agricultural College Press, Laiyang, China.

Tan, Y., Cheng, J.C., and Qu, R. 2007. Isolation of nitrate reducing bacteria from oilfield produced water and their inhibition to sulfate reduction. Chinese Journal of Applied and Environmental Biology 13:390-394.

Tian, M. 2014. The research of mechanism and effect on dredger fill improved by industrial and agricultural waste. Tianjin University of Technology, Tianjin, China.

Tuteja, N. 2007. Mechanisms of high salinity tolerance in plants. Method in Enzymology 428:419-38.

Wang, G.L., Chen, H.H., Bi, M., and Li, S.P. 2012. Bioremediation of chlorothalonil-contaminated soil by utilizing Pseudomonas sp. strain CTN-3. Chinese Journal of Applied Ecology 23(3):807-811.

Wang, G., Wu, T., Xiang, J., and Huang, M. 2011. Study on improve effect of phosphogypsum on brackish dredged sediment. Journal of Anhui Agricultural Sciences 28:17249-17251.

Waskiewicz, A., Beszterda, M., and Golinski, P. 2013. Role in plant signaling under salt stress. Springer, New York, USA.

Weiner, R., Seagren, E., Arnosti, C., and Quintero, E. 1999. Bacterial survival in biofilms: probes for exopolysaccharide and its hydrolysis, and measurements of intra-and interphase mass fluxes. Methods in Enzymology 3:403-426.

Wills, S.A., Williams, C.O., Duniway, M.C., Veenstra, J., Seybold, C., and Presley, D. 2016. Human land-use and soil change. p. 351-371. In West, L.T., Singer, M.J., and Hartemink, A.E. (eds.) The soils of the USA, World Soils Book Series. Springer International Publishing, New York, USA.

Wold, S., Esbensen, K., and Geladi, P. 1987. Principal component analysis. Chemometrics \& Intelligent Laboratory Systems 2(1-3):37-52.

Wu, G.H., Li, W.Q., and Zheng, H.Q. 2007. Water pollution characteristics in Tianjin sea are of the Chinese Bohai Bay. Acta Oceanologica Sinica 29(2):143-149.

Xiao, H., Zhang, Y., Zhang, Z., Zhu, L., You, C., and Tang, X.X. 2009. A preliminary study on the bacterial diversity in surface sediments from the coastal water of Qingdao and Weihai in summer and winter. Periodical of Ocean University of China 39:641-646.

Xie, L.W., Zhong, J., Cao, F.X., Li, J.J., and Wu, L.C. 2015. Evaluation of soil fertility in the succession of karst rocky desertification using principal component analysis. Solid Earth 6(2):3333-3359.

Xiong, J., Liu, Y., Lin, X., Zhang, H., Zeng, J., and Hou, J. 2012. Geographic distance and pH drive bacterial distribution in alkaline lake sediments across Tibetan Plateau. Environmental Microbiology 14(9):2457-2466.

Zhu, G.C. 2009. Initial studies on structure and function of microbial community in sediment from Lianyungang Coastal. p. 23-27. Jiangnan University, Wuxi, Jiangsu, China.

Zou, G., Su, D., and Huang, M. 2010. Effect of planting Suaeda salsa on improvement of dredger filled soil. Pratacultural Science 27(4):51-56.

Zumft, G. 1997. Cell biology and molecular basis of denitrification. Microbiology and Molecular Biology Review 61:533-536. 